\title{
Magzati és anyai betegségek kockázata 40 évesnél idősebb édesanyák esetén
}

\author{
Vanya Melinda dr. ${ }^{1,3}$ - Szili Károly dr. ${ }^{2,3}$ \\ Devosa Iván ${ }^{3}$ - Bártfai György dr. ${ }^{1}$
${ }^{1}$ Szegedi Tudományegyetem, Általános Orvostudományi Kar, Szent-Györgyi Albert Klinikai Központ, Szülészeti és Nőgyógyászai Klinika, Szeged
${ }^{2}$ Mediteam Zrt., Szeged \\ ${ }^{3}$ Kecskeméti Főiskola, Tanítóképző Főiskolai Kar, Egészségtudományi és Egészségfejlesztő Kutató Csoport,
} Kecskemét

\begin{abstract}
Az elmúlt néhány évtizedben a gyermeket vállaló nők életkora emelkedő trendet mutat. Számos tanulmány mutatott rá az anyai életkor emelkedésének és a terhesség kimenetelének összefüggésére a vetélés, a halvaszületés, a praeeclampsia, a terhességi hipertenzió, a gestatiós diabetes mellitus, a koraszülés, a kis vagy nagy gesztációs korú újszülött, valamint az elektív vagy sürgősségi császármetszés kapcsán. E vizsgálatok egymásnak ellentmondó megállapításokról számoltak be. A jelenlegi közlemény célja az, hogy összefoglalja az előrehaladott anyai életkor és a terhesség kimenetele közti, bizonyítékokon alapuló információkat. Orv. Hetil., 2015, 156(49), 1987-1990.
\end{abstract}

Kulcsszavak: előrehaladott anyai életkor, magzati-anyai szövődmények, terhesség kimenetele

\section{Risk of maternal and fetal disease among women older than 40 years}

\begin{abstract}
A rising trend in advanced maternal age has been observed over the last few decades. Several studies have assessed the association between advanced maternal age and adverse pregnancy outcome, including miscarriage, stillbirth, preeclampsia, gestational hypertension, gestational diabetes mellitus, preterm birth, delivery of a small- or large-forgestational-age neonates and elective or emergency Cesarean section. These studies reported contradictory findings. The aim of the present paper is to summarize the evidence-based information regarding advanced maternal age and pregnancy outcomes.
\end{abstract}

Keywords: advanced maternal age, fetal, maternal complications, pregnancy outcome

Vanya, M., Szili, K., Devosa, I., Bártfai, Gy. [Risk of maternal and fetal disease among women older than 40 years]. Orv. Hetil., 2015, 156(49), 1987-1990.

(Beérkezett: 2015. augusztus 25.; elfogadva: 2015. október 3.)

\section{Rövidítések}

CS = császármetszés; GDM = gestatiós diabetes mellitus; LGA = large for gestational age; SGA = small for gestational age

Napjainkban az Európai Unió számos országában elfogadott trend, hogy egyre több nő vállal gyermeket 35 , sőt 40 éves kor felett [1, 2, 3, 4, 5]. Számos tanulmány eredményei arra engednek következtetni, hogy az előre- haladott anyai életkor és a terhesség kimenetele - beleértve a vetélés, halvaszületés, praeeclampsia, terhességi hipertenzió, terhességi cukorbetegség (GDM), koraszülés, kis súlyú (SGA), valamint a nagy súlyú (LGA) újszülött és elektív vagy sürgősségi császármetszés - között szoros korreláció van. Egyes tanulmányok eredményei azonban ellentmondásosak $[6,7,8,9,10,11,12,13$, $14,15]$. A jelen összefoglalónk célja, hogy áttekintsük az anyai életkor és az anyai, valamint magzati komplikációk összefüggéseit. 


\section{Történeti háttér}

Kultúrtörténetileg a gyermekvállalás anyai életkorát tekintve három korszak különíthető el.

- Az első sok ezer évig tartott, amikor a nők kiaknázták természetes termékenységüket, és átlagosan akár 11 gyermeket is világra hozhattak. Ez azt jelentette, hogy 16-18 éves koruktól szinte folyamatosan terhesek voltak vagy szoptattak, és 45 éves koruk körül elmaradt a menstruációjuk. Figyelembe véve azonban a magas perinatológiai mortalitást, szükség is volt a magas születésszámra a magyarországi populáció csökkenésének megakadályozása miatt.

- A következő korszak a XX. század második felére esett, amikor a hatékony fogamzásgátlás és a nők társadalmi helyzetének változása miatt a családonkénti gyermekszám drasztikusan csökkent (jelenleg hazánkban az átlagos termékenységi arányszám 1,3), és e kevés gyermeket döntően a huszonéves nők hozták a világra. Viszont a perinatalis diagnosztika fejlődésével, a terhesgondozó hálózat kiépülésével, a neonatalis ellátás színvonalának jelentős emelkedésével drasztikusan csökkent mind a korai, mind a késői magzati és csecsemőhalálozás.

- Jelenleg tanúi vagyunk a harmadik korszaknak, amikor Európában és az egész világon a várható élettartam egyre inkább növekszik (Magyarországon: férfiaknál 66,3 év, nóknél 75,1 év [2]), s az egyre magasabb iskolai végzettséget szerzett és a társadalomban mind fontosabb szerepet játszó nók keresik az optimális megoldást két küldetésük: a hagyományos és kizárólagos anyaszerepük, valamint a férfiakkal vetélkedő, otthonukon kívüli munkavállalásuk között. Ennek jele a gyermekvállalásuk kitolódása, aminek sikeréhez hozzájárulnak az orvostudomány és az egészségügyi ellátás dinamikus fejlődése adta lehetőségek is. Hazánkban is egyre több nő lesz várandós 35 , sőt 40 év felett, ez újabb kihívást jelent a társadalom számára.

\section{Gyermekvállalás 40 év felett}

Az elmúlt évtizedek szülészeti gyakorlata alapvető változásokon ment keresztül. Ezek jelentős része az asszisztált reprodukciós technikák elterjedésének és azok fejlődésének köszönhető. Ehhez természetesen hozzájárultak a társadalmi változások is, mint az első gyermek vállalásának átlagosan egy évtizeddel későbbre tolódása. A női karrier elfogadása, a nemi szerepek összemosódása, a késóbb kötött házasságok, illetve párkapcsolatok következtében nem ritka, hogy napjainkban a gyermekvállalás a 4-5. évtizedre tolódik. Ebben az életszakaszban a fogamzás több szempontból is nehézséget okozhat. A harmincas életévek elején elkezd csökkenni a megtermékenyíthetőség, évente 3-5\%-kal csökken a teherbe esés lehetősége, igazán drámai változás a negyvenes évek után figyelhető meg. A nők 20-as életéveiben 12-15\%-os valószínüséggel következik be vetélés, ez az arány 40 év felett az 50\%-ot is eléri $[1,2,3,4,5,6]$.

Mindezek mind az asszisztált reprodukció esetén, mind a természetes fogamzás során megfigyelhetők. Gyakori az anovulatiós ciklus, meghatározó jelenség a korai petefészek-kimerülés. Ezekben az esetekben aszszisztált reprodukciós technikákat szükséges igénybe venni. Az asszisztált reprodukciós technikák során a megtermékenyülési arány 40 év alatt 45\% körüli, 40 év felett viszont csak $15 \%$. Ha a hazavitt gyermekek arányait nézzük, akkor még szomorúbb a helyzet: a fiatalabb csoportban 40\%, míg az idősebb nóknél csak 5-7\%. A különböző meddőségi kezelési eljárások során a csökkenő eredményesség egyik meghatározó oka a romló petesejtminőségben keresendő. A petesejt-adományozás szükségessége 40 év felett exponenciálisan nő; míg 35 év alatt 5\%, addig 45 év felett ez az arány 77\%. A kromoszóma-rendellenességek 35 év felett jelentős kockázati tényezőt jelentenek, elsősorban a triszómiák (számfeletti kromoszómával rendelkező állapotok) gyakorisága emelkedik $[8,11,12]$.

Az életkorral együtt járó változásoknak tehát komoly egészségügyi következményei vannak. Az idősebb életkorban vállalt várandósság magasabb kockázatot jelent mind az édesanya, mind a magzat számára.

\section{Az igen előrehaladott anyai életkor}

Az idösebb („elörehaladott”) anyai életkort a 35. életévtől számítja a szakirodalom. Az utóbbi években bevezettek egy újabb meghatározást, amely az igen elórehaladott életkorra, a 45 év felettiekre vonatkozik $[1,2,3,4,5,6]$.

Az Egyesült Államokban a 30 év feletti nők gyermekvállalási aránya az 1960-as évektől napjainkig háromszorosára, azaz 8,6\%-ról 25,4\%-ra nőtt. A növekedés a 35 év felettieknél hatszoros (1,3\%-ról 8,3\%) és a 45 év felettieknél 15-szörös (0,1\%-ról 1,5\%) [1, 2].

$\mathrm{Az}$ anyai életkor emelkedése Európában is megfigyelhető, különösen Nyugat- és Dél-Európában. A 35 év felett szülő nők aránya Lengyelországban is számottevően magas (11\%). Az ilyen idős korban gyermeket vállalók aránya éppen a legalacsonyabb termékenységi arányt mutató két dél-európai országban: Spanyolországban és Olaszországban a legmagasabb (18\%), de 15-17\%-ot tesz ki Svédországban, Hollandiában és Svájcban is $[3,4$, $5,6]$.

1990-2000 között hazánkban a harmincévesnél idősebb kismamák aránya 18\%-ról 29\%-ra emelkedett. Az elmúlt másfél évtizedben 4,3 évvel nőtt az anyák átlagéletkora, amely 2008-ban az első gyermeküket szülő nőknél 27,4 év volt, illetve az egyetemet végzett nők átlagosan 30 éves koruk körül hozták világra első gyermeküket. Ehhez hasonló az anyai életkor átlaga Közép- és Kelet-Európa más országaiban. Dél-Európában 30, Észak- és Nyugat-Európában pedig 29 év a szülőnők átlagéletkora $[3,4,5,6]$. 


\section{Növekvő veszélyek az anya életkorának előrehaladásával}

Ma már számos közlemény $[8,9,10,11,12,13,14,15$, $16,17,18,19,20,21,22,23,24,25,26,27,28,29$, $30,31,32,33,34,35,36,37,38,39,40,41,42,43$, $44,45,46,47,48,49,50$ ] foglalkozik az idősebb anyai életkorban vállalt terhességek kimenetelével. Az eredmények szerint az átlagos születési súly alacsonyabb volt az idősebb korcsoportokban (esélyhányados: 1,1). A legnagyobb valószínűséggel kialakuló szövődmények a 45 év feletti, először szülők körében a 30-34 éves korosztályhoz képest a magas vérnyomás betegség (esélyhányados: 1,1), a cukorbetegség (esélyhányados 1,49) és 32. hét elötti koraszülés (esélyhányados: 1,32). A császármetszés gyakorisága először szülőknél és többedszer szülőknél egyaránt lényegesen magasabb a 30 éves korosztályhoz képest. A szülés utáni nagyfokú vérvesztés valószínűsége körülbelül másfélszeres a 45 év feletti terhesek körében. A császármetszés kiugróan magas arányában (elektív CS esélyhányados: 2,17, sürgősségi CS esélyhányados: 1,95) szerepet játszik a defenzív orvosi döntéshozatal, a nehéz hüvelyi szülés traumatizáló hatásától és a magzat agykárosodásától való félelem, és csak kisebb mértékben a hüvelyi szülés után esetleg kialakuló süllyedéses panaszok megelőzése [50].

Khalil és mtsai metaanalízisükben azt találták [50], hogy 45 év felett a krónikus anyai betegségek és a praeeclampsia (magas vérnyomással, fehérjevizeléssel járó betegség) 2,3-szer gyakrabban fordulnak elő, mint fiatalabb életkorban. A szülésvezetés módja az esetek döntő részében a császármetszés $(78,5 \%)$ volt, de ugyanakkor gyakrabban fordult elő szülés után súlyos vérzés, láz és transzfúzió szülkségessége. A császármetszések javallatai az anya kérésére végzett mütét, elozzetes császármetszés, lepénytapadási rendellenességek, medencevégü fekvés és a koraszülés voltak. A fentiek miatt hosszabb kórházi ápolásra volt szükség. A magasabb koraszülési arány következtében a koraszülött intenzív osztályon való elhelyezés is gyakoribb volt $(10,7 \%)$. A terhességek kimenetele természetesen az 50 év feletti terhesek között volt a legroszszabb.

\section{Következtetések}

Az idősebb életkorban (különösen a 45 év felett) vállalt terhességek aránya kicsi az összes élveszületéshez viszonyítva. Számuk azonban az utóbbi évtizedben szignifikánsan nőtt, különösen az asszisztált reprodukciós technikák folyamatos fejlődésének köszönhetően. Az idősebb anyai életkorban a várandósoknál növekszik az egészségügyi kockázat. Ennek oka az, hogy ebben az életkorban a krónikus betegségek már manifesztálódnak, csökken a szív- és érrendszeri terhelhetőség és a terhesség okozta változásokhoz való alkalmazkodási képesség.

További megpróbáltatást jelent a későn gyermeket vállaló házaspárok számára, hogy a magzati kromoszóma- rendellenességek száma is magasabb, mint a 30 évnél fiatalabbak körében. Az idős korban vállalt terhességek előtt szükséges a házaspár részletes tájékoztatása a lehetséges anyai és magzati kockázatokról.

Magának a várandósságnak a gondozása olyan szülészeti egységek feladata, ahol rendelkeznek megfelelő tapasztalattal az ilyen betegek komplex ellátásában, hiszen ezekben az esetekben több, szélesebb körű diagnosztikai eljárás igénybevételére lehet szükség. Gyakrabban kell számolni ebben az életkorban kórházi ápolás szükségességével, nagyobb a valószínúsége a császármetszésnek.

Természetesen az igen idős korban vállalt terhességeknek nemcsak a nehézségeit kell számba venni, hanem az előnyeit is. Ezek az átlagosnál is tudatosabban vállalt terhességek. A gyermekek olyan környezetbe születnek, ahol nagy odafigyelés és anyagi biztonság várja őket.

Anyagi támogatás: A közlemény megírása anyagi támogatásban nem részesült.

Szerzői munkamegosztás: V. M., SZ. K.: A kézirat elkészítése. D. I.: A kézirat javítása. B. Gy.: Ötletgazda. A cikk végleges változatát valamennyi szerző elolvasta és jóváhagyta.

Érdekeltségek: A szerzőknek nincsenek érdekeltségeik.

\section{Irodalom}

[1] World Health Organization: Atlas of Health in Europe, 2nd edition. World Health Organization, 2008. http://www.euro.who. int/Document/E91713.pdf

[2] Australian Bureau of Statistics: Births 2007. http://www.ausstats.abs.gov.au/ausstats/subscriber.nsf/0/DC32A0611500BA A0CA2574EF00142139/\$File/33010_2007.pdf

[3] Statistics New Zealand: Demographic Trends: 2007. Statistics New Zealand, 2008. http://www.stats.govt.nz/NR/rdonlyres/DB3A801B-3745-4B4C-8D34-F5F69A9139.

[4] Bushnik, T., Garner, R.: The children of older first-time mothers in Canada: Their health and development. Statistics Canada, September 2008. http://www.statcan.gc.ca/pub/89-599$\mathrm{m} / 89-599-\mathrm{m} 2008005$-eng.pdf.

[5] Centers for Disease Control and Prevention: Births: Final data for 2006. National Vital Statistics Reports, 2009, 57(7). http:// www.cdc.gov/nchs/data/nvsr/nvsr57/nvsr57_07.pdf.

[6] Royal College of Obstetricians and Gynaecologists: RCOG Statement on later maternal age. Royal College of Obstetricians and Gynaecologists, London, 2009. http://www.rcog.org.uk/ what-we-do/campaigning-and-opinions/statement/rcogstatement-later-maternal-age

[7] Huang, L., Sauve, R., Birkett, N., et al.: Maternal age and risk of stillbirth: a systematic review. CMAJ, 2008, 178(2), 165-172.

[8] Joseph, K. S., Allen, A. C., Dodds, L., et al.: The perinatal effects of delayed childbearing. Obstet. Gynecol., 2005, 105(6), 14101418.

[9] Odibo, A. O., Nelson, D., Stamilio, D. M., et al.: Advanced mater nal age is an independent risk factor for intrauterine growth restriction. Am. J. Perinatol., 2006, 23(5), 325-328.

[10] Bianco, A., Stone, J., Lynch, L., et al.: Pregnancy outcome at age 40 and older. Obstet. Gynecol., 1996, 87(6), 917-922. 
[11] Dulitzki, M., Soriano, D., Schiff, E., et al.: Effect of very advanced maternal age on pregnancy outcome and rate of cesarean delivery. Obstet. Gynecol., 1998, 92(6), 935-939.

[12] Berkowitz, G. S., Skovron, M. L., Lapinski, R. H., et al.: Delayed childbearing and the outcome of pregnancy. N. Engl. J. Med., 1990, 322(10), 659-664.

[13] Wang, Y., Tanbo, T., Abyholm, T., et al.: The impact of advanced maternal age and parity on obstetric and perinatal outcomes in singleton gestations. Arch. Gynecol. Obstet., 2011, 284(1), 3137.

[14] Kirz, D. S., Dorchester, W., Freeman, R. K.: Advanced maternal age: the mature gravida. Am. J. Obstet. Gynecol., 1985, 152(1), 7-12.

[15] Snijders, R. J., Noble, P., Sebire, N., et al.: UK multicentre project on assessment of risk of trisomy 21 by maternal age and fetal nuchal-translucency thickness at 10-14 weeks of gestation. Lancet, 1998, 352(9125), 343-346.

[16] Syngelaki, A., Chelemen, T., Dagklis, T., et al.: Challenges in the diagnosis of fetal non-chromosomal abnormalities at 11-13 weeks. Prenat. Diagn., 2011, 31(1), 90-102.

[17] Cleary-Goldman, J., Malone, F. D., Vidaver, J., et al.: Impact of maternal age on obstetric outcome. Obstet. Gynecol., 2005, 105(5 Pt 1), 983-990.

[18] Ozalp, S., Tanir, H. M., Sener, T., et al.: Health risks for early (< or $=19)$ and late $(>$ or $=35$ ) childbearing. Arch. Gynecol. Obstet., 2003, 268(3), 172-174

[19] Bobrowski, R. A., Bottoms, S. F.: Underappreciated risks of the elderly multipara. Am. J. Obstet. Gynecol., 1995, 172(6), 17641767.

[20] Dietl, A., Cupisti, S., Beckmann, M. W., et al.: Pregnancy and obstetrical outcomes in women over 40 years of age. Geburtshilfe Frauenheilkd., 2015, 75(8), 827-832.

[21] Obed, S. A., Armah, J. O., Wilson, J. B.: Advanced maternal age and pregnancy. West Afr. J. Med., 1995, 14(4), 198-201.

[22] Gilbert, W. M., Nesbitt, T. S., Danielsen, B.: Childbearing beyond age 40: pregnancy outcome in 24,032 cases. Obstet. Gynecol., 1999, 93(1), 9-14.

[23] Naeye, R. L.: Maternal age, obstetric complications, and the outcome of pregnancy. Obstet. Gynecol., 1983, 61(2), 210-216.

[24] Prysak, M., Lorenz, R. P., Kisly, A.: Pregnancy outcome in nulliparous women 35 years and older. Obstet. Gynecol., 1995, 85(1), 65-70.

[25] Seoud, M. A., Nassar, A. H., Usta, I. M., et al.: Impact of advanced maternal age on pregnancy outcome. Am. J. Perinatol., $2002,19(1), 1-8$.

[26] Duckitt, K., Harrington, D.: Risk factors for pre-eclampsia at antenatal booking: systematic review of controlled studies. BMJ, $2005,330(7491), 565$

[27] Bayrampour, H., Heaman, M.: Advanced maternal age and the risk of cesarean birth: a systematic review. Birth, 2010, 37(3), 219-226.

[28] Ludford, I., Scheil, W., Tucker, G., et al.: Pregnancy outcomes for nulliparous women of advanced maternal age in South Australia, 1998-2008. Aust. N. Z. J. Obstet. Gynaecol., 2012, 52(3), 235-241

[29] Favilli, A., Pericoli, S., Acanfora, M. M., et al.: Pregnancy outcome in women aged 40 years or more. J. Matern. Fetal Neona tal Med., 2012, 25(8), 1260-1263.

[30] Vercellini, P., Zuliani, G., Rognoni, M. T., et al.: Pregnancy at forty and over: a case-control study. Eur. J. Obstet. Gynecol. Reprod. Biol., 1993, 48(3), 191-195.

[31] AlShami, H. A., Kadasne, A. R., Khalfan, M., et al.: Pregnancy outcome in late maternal age in a high-income developing country. Arch. Gynecol. Obstet., 2011, 284(5), 1113-1116.
[32] Chan, B. C., Lao, T. T.: Effect of parity and advanced maternal age on obstetric outcome. Int. J. Gynaecol. Obstet., 2008, 102(3), 237-241.

[33] Poon, L. C., Kametas, N. A., Chelemen, T., et al.: Maternal risk factors for hypertensive disorders in pregnancy: a multivariate approach. J. Hum. Hypertens., 2010, 24(2), 104-110.

[34] Kolovou, G. D., Bilianou, H. G.: Influence of aging and menopause on lipids and lipoproteins in women. Angiology, 2008, 59(2 Suppl.), 54S-57S.

[35] Poon, L. C., Karagiannis, G., Staboulidou, I., et al.: Reference range of birth weight with gestation and first-trimester prediction of small-for-gestation neonates. Prenat. Diagn., 2011, $31(1), 58-65$.

[36] Ishii, M., Yamauchi, T., Matsumoto, K., et al.: Maternal age and reproductive function in female Sprague-Dawley rats. J. Toxicol. Sci., 2012, 37(3), 631-638.

[37] Kajanoja, P., Widholm, O.: Pregnancy and delivery in women aged 40 and over. Obstet. Gynecol., 1978, 51(1), 47-51.

[38] Barkan, S. E., Bracken, M. B.: Delayed childbearing: no evidence for increased risk of low birth weight and preterm delivery. Am. J. Epidemiol., 1987, 125(1), 101-109.

[39] Laskov, I., Birnbaum, R., Maslovitz, S., et al.: Outcome of singleton pregnancy in women $\geq 45$ years old: a retrospective cohort study. J. Matern. Fetal Neonatal Med., 2012, 25(11), 21902193.

[40] Kozinszky, Z., Orvos, H., Zoboki, T., et al.: Risk factors for cesarean section of primiparous women aged over 35 years. Acta Obstet. Gynecol. Scand., 2002, 81(4), 313-316.

[41] Ezra, Y., McParland, P., Farine, D.: High delivery intervention rates in nulliparous women over age 35. Eur. J. Obstet. Gynecol. Reprod. Biol., 1995, 62(2), 203-207.

[42] De Weger, F. J., Hukkelhoven, C. W., Serroyen, J., et al.: Advanced maternal age, short interpregnancy interval, and perinatal outcome. Am. J. Obstet. Gynecol., 2011, 204(5), 421.el-421e9.

[43] Salem Yaniv, S., Levy, A., Wiznitzer, A., et al.: A significant linear association exists between advanced maternal age and adverse perinatal outcome. Arch. Gynecol. Obstet., 2011, 283(4), 755759.

[44] Jolly, M., Sebire, N., Harris, J., et al.: The risks associated with pregnancy in women aged 35 years or older. Hum. Reprod., 2000, 15(11), 2433-2437.

[45] O'Leary, C. M., de Klerk, N., Keogh, J., et al.: Trends in mode of delivery during 1984-2003: can they be explained by pregnancy and delivery complications? BJOG, 2007, 114(7), 855-864.

[46] Treacy, A., Robson, M., O'Herlihy, C.: Dystocia increases with advancing maternal age. Am. J. Obstet. Gynecol., 2006, 195(3), 760-763.

[47] Yuan, W., Steffensen, F. H., Nielsen, G. L., et al.: A populationbased cohort study of birth and neonatal outcome in older primipara. Int. J. Gynaecol. Obstet., 2000, 68(2), 113-118.

[48] Cnattingius, R., Cnattingius, S., Notzon, F. C.: Obstacles to reducing cesarean rates in a low-cesarean setting: the effect of maternal age, height, and weight. Obstet. Gynecol., 1998, 92(4 Pt l), 501-506.

[49] Delbaere, I., Verstraelen, H., Goetgeluk, S., et al.: Pregnancy outcome in primiparae of advanced maternal age. Eur. J. Obstet. Gynecol. Reprod. Biol., 2007, 135(1), 41-46.

[50] Khalil, A., Syngelaki, A., Maiz, N., et al.: Maternal age and adverse pregnancy outcome: a cohort study. Ultrasound Obstet. Gynecol., 2013, 42(6), 634-643.

(Vanya Melinda dr., e-mail: vmelinda74@gmail.com) 